\title{
CHARACTERIZATION OF THE LOW ALLOY STEEL MODIFIED SUPERFICIALLY WITH IONS OF TITANIUM AND NITROGEN
}

\author{
CARACTERIZACIÓN DEL ACERO DE BAJA ALEACIÓN MODIFICADO \\ SUPERFICIALMENTE CON IONES DE TITANIO Y NITRÓGENO
}

\author{
CARACTERIZAÇÃO DO AÇO DE BAIXA LIGA ALTERADO \\ SUPERFICIALMENTE COM IONES DE TITÂNIO E NITROGÊNIO
}

Ely-Dannier Valbuena-Niño ${ }^{1-2 *}$, Linda Gil ${ }^{3}$, Luis Hernández-Molina ${ }^{3}$, José-José Barba-Ortega ${ }^{4}$ and Valeriy Dugar-Zhabon ${ }^{2}$

\author{
1 Universidad Politécnica de Madrid, Madrid, España \\ ${ }^{2}$ Universidad Industrial de Santander, Bucaramanga, Colombia \\ ${ }^{3}$ Universidad Nacional Experimental Politécnica, Puerto Ordaz, Venezuela \\ ${ }^{4}$ Universidad Nacional de Colombia, Bogotá, Colombia \\ e-mail: deydannv@gmail.com
}

(Received: Feb. 03, 2016; Accepted: May 31, 2016)

\begin{abstract}
The three-Dimensional lon Implantation technique (3DII) causes ions to collide with a solid surface in a perpendicular way regardless of the geometry of the solid (Khvesyuk \& Tsygankov, 1997; Dougar-Jabon, Dulce-Moreno \& Tsygankov, 2002). The steel AISI SAE 4140 has been used as substrate because of its wide use in the transport of oil industry, the specimens of steel underwent surface modification with Titanium ions $(\mathrm{Ti})$ and the combined ions of titanium and nitrogen $(\mathrm{Ti}+\mathrm{N})$, with energy of $10 \mathrm{keV}$ for $5 \mathrm{~min}$ and $10 \mathrm{~min}$. The superficially modified and unmodified specimens were characterized by Electrochemical Impedance Spectroscopy (EIS), noting among the most outstanding results the electrochemical double layer system capacitive characteristics under all tested conditions, the best corrosion performance was obtained for implanted substrates with $\mathrm{Ti}$ ions for $10 \mathrm{~min}$, having a charge transfer resistance much higher than those implanted with $\mathrm{Ti}+\mathrm{N}$ and the non-implanted. Additionally it was determined that all the implanted systems can be simulated by using one equivalent circuit with a constant phase element instead of a capacitor and the non implanted substrate from day 15 can be simulated through another equivalent circuit.
\end{abstract}

Keywords: Chromium-molybdenum steels, Corrosion, Spectroscopy ionic implantation.

How to cite: Valbuena-Niño, E. D., Gil, L., Hernández-Molina, L., Barba-Ortega, J. J. \& Dugar-Zhabon, V. (2016). Characterization of the low alloy steel modified superficially with ions of titanium and nitrogen. CT\&F - Ciencia, Tecnología y Futuro, 6(3), 127-138.

*To whom correspondence should be addressed 


\section{RESUMEN}

\begin{abstract}
T a técnica de implantación iónica tridimensional (3DII) consigue que los iones a implantar colisionen perpendicularmente con la superficie sin importar la geometría del sólido (Khvesyuk \& Tsygankov, 1997; Dougar-Jabon et al., 2002). Se ha usado un acero de herramientas AISI SAE 4140 como sustrato por su amplio uso en la industria del transporte de hidrocarburos. Las probetas de acero se sometieron a la modificación superficial con iones Titanio (Ti) y Titanio +Nitrógeno $(\mathrm{Ti}+\mathrm{N})$ a energía de $10 \mathrm{keV}$ durante $5 \mathrm{~min}$ y $10 \mathrm{~min}$. Los sustratos modificados y no modificados superficialmente fueron caracterizados mediante la técnica de espectroscopia de impedancia electroquímica (EIS), observando entre los resultados más resaltantes que la doble capa electroquímica del sistema en estudio presenta características capacitivas en todas las condiciones evaluadas, donde el mejor desempeño frente a la corrosión lo presentan los sustratos implantados con iones de Ti durante $10 \mathrm{~min}$, debido a que poseen una resistencia a la transferencia de carga mucho mayor que los implantados con iones de $\mathrm{Ti}+\mathrm{N}$ y los no implantados. Adicionalmente se determinó que todos los sistemas implantados pueden ser simulados mediante el uso de un circuito equivalente, el cual posee un elemento de fase constante en lugar de un capacitor y que el sustrato sin implantar a partir del día de inmersión 15 se puede simular a través de otro circuito equivalente diferente.
\end{abstract}

Palabras clave: Aceros cromo-molibdeno, Corrosión, Espectroscopia, Implantación iónica.

\section{RESUMO}

$\Delta$ técnica de implantação iônica tridimensional (3DII) consegue que os iones a serem implantados colidam perpendicularmente com a superfície sem importar a geometria do sólido (Khvesyuk \& Tsygankov, 1997; Dougar-Jabon et al., 2002). Foi usado um aço de ferramentas AISI SAE 4140 como substrato sendo que ele é extensivamente utilizado na indústria de transporte de hidrocarbonetos. Os espécimenes de aço foram submetidos à alteração superficial com iones de Titânio (Ti) e Titânio + Nitrogênio $(T i+N)$ com energia de $10 \mathrm{keV}$ durante $5 \mathrm{~min}$ e $10 \mathrm{~min}$. Os substratos alterados e não alterados superficialmente foram caracterizados mediante a técnica de espectroscopia de impedância eletroquímica (EIS), verificando-se entre os resultados mais importantes que a dupla capa eletroquímica do sistema em estudo apresenta características em todas as condições avaliadas, onde o melhor desempenho diante da corrosão é conseguido com os substratos implantados com iones de Ti durante $10 \mathrm{~min}$, por conta deles possuírem uma resistência à transferência de carga muito maior do que aqueles implantados com iones de $\mathrm{Ti}+\mathrm{N}$ e com os não implantados. Adicionalmente, determinou-se que todos os sistemas implantados podem ser simulados mediante o uso de um circuito equivalente, que possui um elemento de fase constante ao invés de um capacitor e que o substrato sem implantar a partir do dia de imersão 15 pode ser simulado através de outro circuito equivalente diferente.

Palavras-chave: Aços cromo-molibdênio, Corrosão, Espectroscopia, Implantação iônica. 


\section{INTRODUCTION}

The low alloy tool steel AISI SAE 4140 contains chromium, molybdenum and manganese as main alloying elements, which confers high resistance to fatigue, abrasion, impact and torsion, in addition, it can achieve high hardness when processed under a suitable heat treatment. The chromium content provides a good resistance to pitting and molybdenum ensures high strength and uniform hardness. Common uses of tool steel AISI SAE 4140 mainly include industrial applications; small pinions, scissors, high strength screws, guides, cam followers, reducing axes, chisels, blocks of plates for filler brackets, punch holder for structural parts, clamps, gauges moulds, brake dice templates, and high strength parts (Peña et al., 2009; V. Niño \& Dougar-Jabon, 2006; Valbuena-Niño, Dulcé $\&$ Dugar-Zhabon, 2010).

In the energy sector, wear and corrosion are main causes of failure of industrial parts and tools. AISI SAE 4140 steel is not exempted from suffering these phenomena, although the alloy contains chromium, it is not enough to achieve properties of stainless steels. A common way or alternative to improve the resistance to corrosion and wear is to modify the surface by applying a coating (Peña et al., 2009; V. Niño \& Dougar-Jabon, 2006; Valbuena-Niño et al., 2010).

Ion implantation is a process by which ions are accelerated to make them collide with a solid surface due to the kinetic energy acquired, these ions penetrate into the crystal lattice causing a series of mutually related processes that alter the physical and chemical behavior of the surface. The 3DII allows ions collide perpendicularly with the solid surface regardless geometry, preserving the monoenergetic characteristics of ions, which offers significant advantages over conventional methods of implantation (Khvesyuk \& Tsygankov, 1997; DougarJabon et al., 2002).

$3 \mathrm{DII}$ technique is performed at very low pressures (about $0.6 P a$ ), which decreases the risk of contamination and the plasma generated in the high voltage discharge is self sustained (not need support plasma (Khvesyuk \& Tsygankov, 1997; Dougar-Jabon et al., 2002) that behaves as an ion source, which acquire energy of kilo-electron-volts ( $\mathrm{keV}$ ) range (Dulcé-Moreno et al., 2011; Parada-Becerra et al., 2012; V. Niño, Peña, Reyes \& Dugar-Zhabon, 2013; V. Niño, Salinas, Peña $\&$ Chinchilla, 2011). This research focuses on studying the electrochemical interaction surface-electrolyte of the steel AISI SAE 4140 implanted and non-implanted with $\mathrm{Ti}$ and $\mathrm{Ti}+\mathrm{N}$ ions, using the Electrochemical Impedance Spectroscopy (EIS) technique.

\section{METHODOLOGY AND MATERIALS}

The substrates of steel AISI SAE 4140 with disk geometry were superficially implanted by hybrid discharges, high voltage and electric arc at low pressures with $\mathrm{Ti}$ and $\mathrm{Ti}+\mathrm{N}$ ions for 5 and $10 \mathrm{~min}$ to voltage of $10 \mathrm{keV}$ (Dugar-Zhabon, Dulcé-Moreno, GarnicaVillamizar \& Valbuena-Niño, 2012; Tsygankov et a., 2011; V. Niño et al., 2012), taking into account the same procedure conducted in the previous research (Hernández et al., 2014).

Electrochemical tests were performed with a potentiostat/galvanostat Gamry Interface 1000 and an electrochemical cell of three electrodes, comprising a bubbler, $\mathrm{pH}$ and temperature sensor, the working electrode (anode), against graphite electrode (cathode), a calomel reference electrode and $3.5 \%$ wt $\mathrm{NaCl}$ as electrolyte. Samples were immersed for 28 days and analyzed at day $0,7,15,21$ and 28 , by EIS technique in $100 \mathrm{kHz}$ to $10 \mathrm{mHz}$ frequency range. Disturbance voltage was $10 \mathrm{mV}$.

\section{RESULTS AND DISCUSSION}

The EIS is a non-destructive technique used to characterize the behavior of an electrochemical electrodeelectrolyte interface, in this technique a harmonic voltage signal with amplitude on the order of millivolts and whose frequency $f$ is applied generally within a range from several millihertz to some tens of kilohertz (Gil, Jiménez \& Staia, 2006), the current flowing through the circuit is detected and recorded to analyze and interpret the complex impedance of the system (Gil et al., 2006). Figure 1 show the Nyquist plot of the substrate in steel AISI SAE 4140 non-implanted and immersed from 0 to 28 days in brind solution.

Based on Figure 1, it becomes evident that with a 


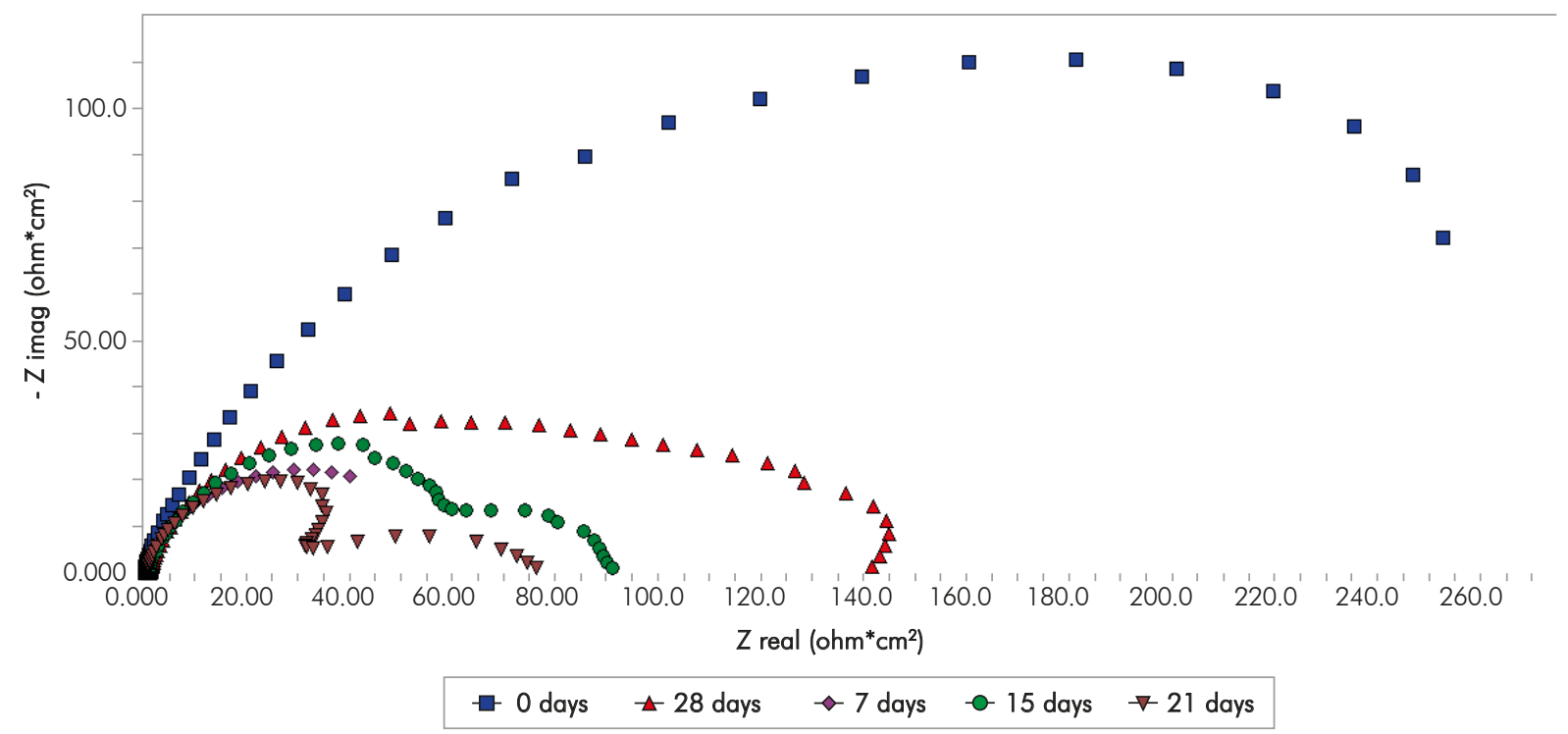

Figure 1. Nyquist plot for non-implanted substrates at different immersion times studied.

15-day immersion, the non-implanted samples behavior of the impedance at low frequencies corresponds to a pseudo-inductive effect, possibly caused by the reactions of adsorption/reabsorption of chemical species in the metal surface resulting in a change in the corrosion rate at that frequency (Escobar et al., 2013). This phenomenon is not seen in the first seven days of immersion.

Next in Figure 2, the Nyquist plot corresponding to the specimens implanted with $\mathrm{Ti}+\mathrm{N}$ to $10 \mathrm{kV}$ for $5 \mathrm{~min}$ is presented. The occurrence of one semicircle in the Nyquist plot indicates that the electrochemical reactions occur with only one time constant $\tau$ (Escobar et al., 2013). Also a reduction of the semicircle diameter with respect to day 0 can be seen, from which a decrease in the charge transfer resistance Rct can be verified after a prolonged immersion.

Figure 4 shows the Nyquist plots for samples implanted with Ti ions to $10 \mathrm{kV}$ for 5 and $10 \mathrm{~min}$. The implantation condition of $10 \mathrm{~min}$ has the singularity that

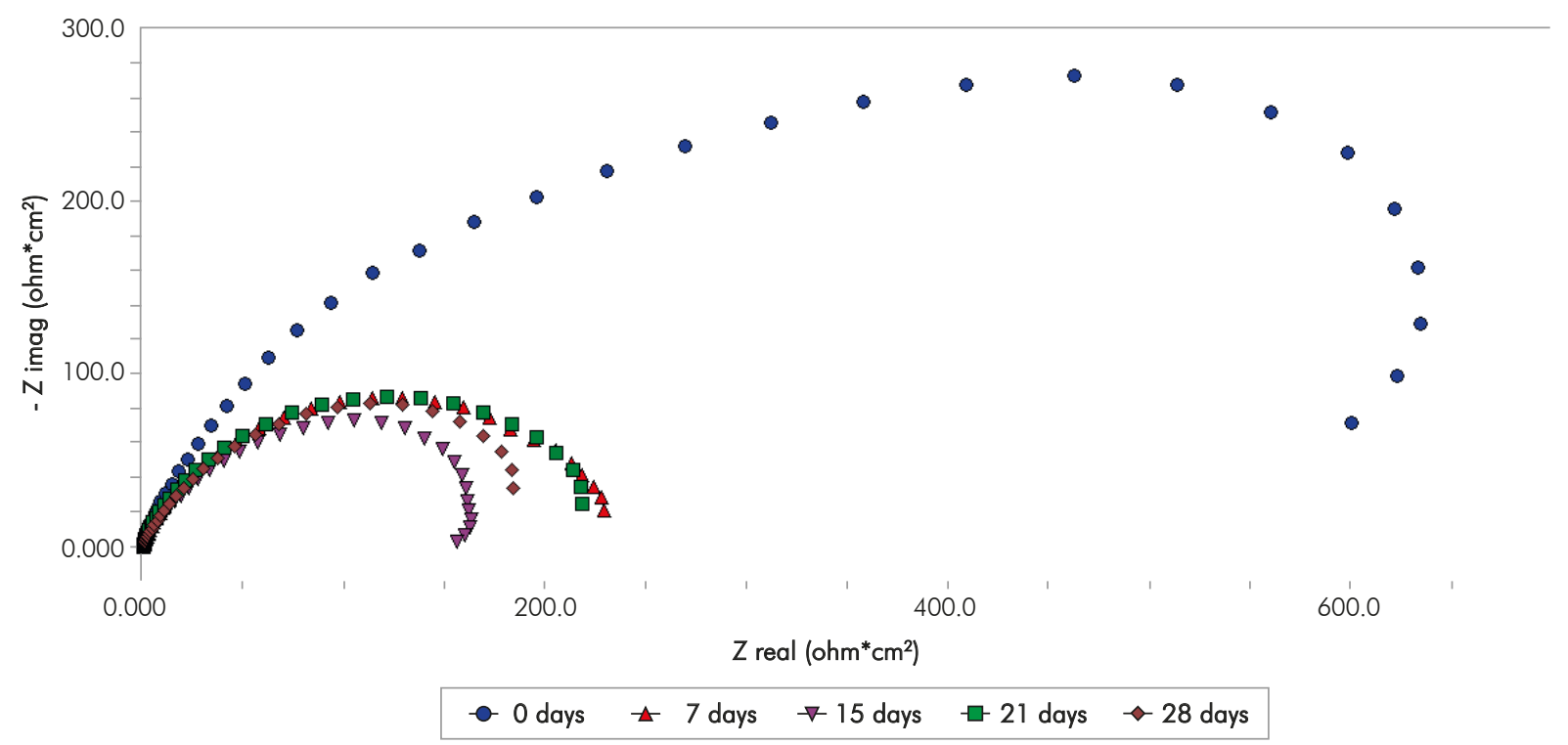

Figure 2. Nyquist plot for specimens implanted with Ti+N $10 \mathrm{kV}$ for $5 \mathrm{~min}$, at different immersion times studied. 
(a)

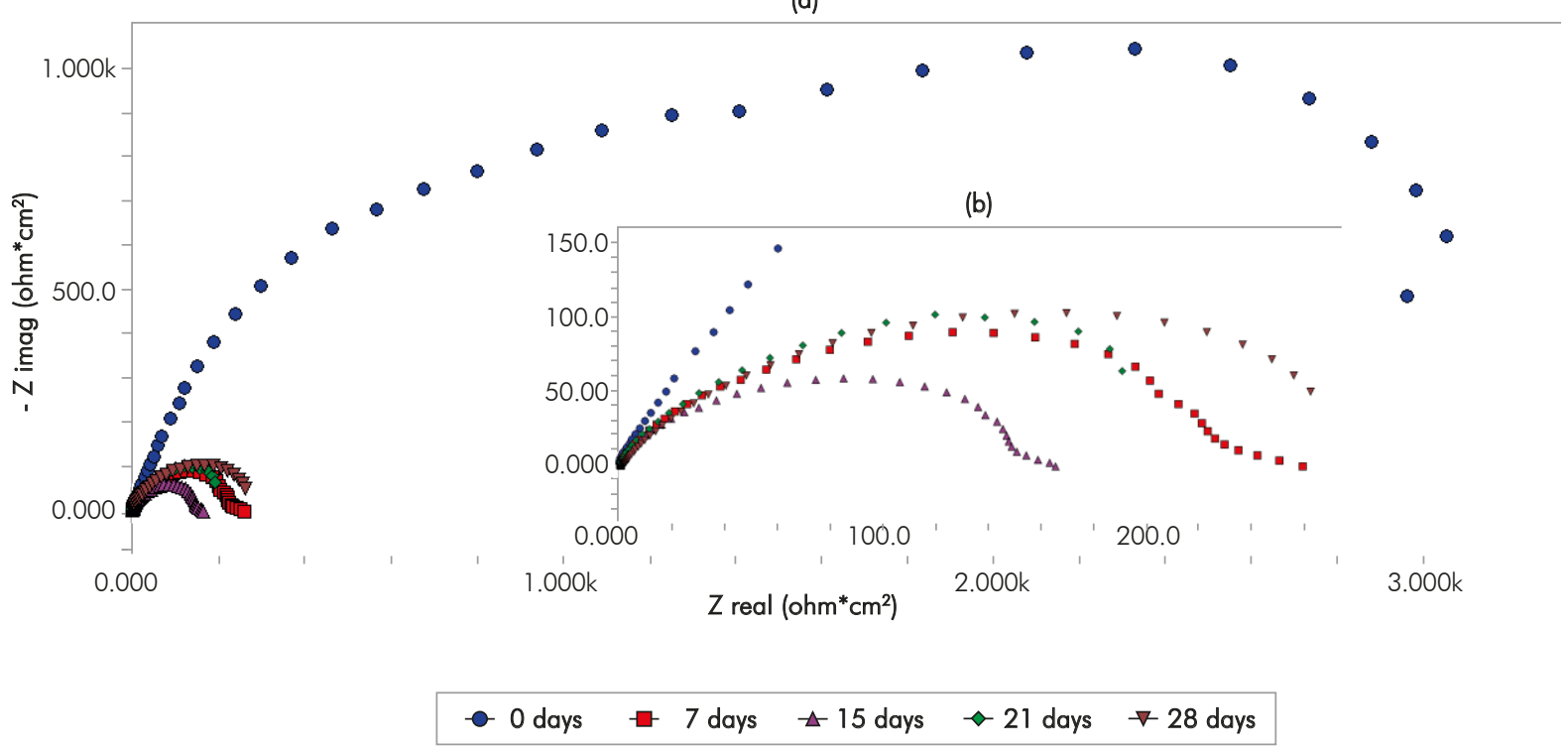

Figure 3. Nyquist plots of the samples implanted with $\mathrm{Ti}+\mathrm{N}$ to $10 \mathrm{kV}$ for $10 \mathrm{~min}$ (a) for all immersion times studied, (b) to observe Zoom detail Nyquist curves.

in the 28th immersion day the semicircle was enlarged and this allows us to observe an increased resistance to charge transfer at the end of the time evaluated in this study.

Before fitting the equivalent circuits, the data was validated using the Kramers-Kronig relations, always obtaining excellent Xi squared values $<10^{-3}$. The equivalent circuit simulation obtained for both implanted and non-implanted surfaces was performed with the Simplex method in the software V6.11 Gamry Echem Analyst, which simulates all the implanted systems behavior through one simple equivalent electric circuit and the non implanted substrate behavior from day 15 through another equivalent circuit; Figure 5 provides details on the two types of circuits that were used for the simulation. The simulation had $\mathrm{X}_{\mathrm{i}}^{2}<10^{-3}$ (goodness of the fit) in almost all the conditions studied.

In circuit (b) CPEads and Rads were used to simulate the pseudo-inductive behavior possibly caused by the reactions of adsorption/reabsorption of chemical species in the metal surface. Figure 6 shows some of the curve fitting for Kramers-Kronig validation and equivalent circuit simulation.

Tables 1 to 5 provide the parameters corresponding to the EIS test applied to steel AISI SAE 4140 modified and not modified superficially with $\mathrm{Ti}$ and $\mathrm{Ti}+\mathrm{N}$ ions. Note that the alpha parameter $\alpha$ indicates that the electrochemical double layer may have a resistive or capacitive behavior, therefore in almost all conditions studied, the electrochemical double layer formed on the interface between samples and the surrounding electrolyte, has a capacitive characteristic because the values of $\alpha$ were always higher than 0.5 .

Figures 7 and 8 show that the capacitance of the electrochemical double layer (CPE) in all the samples increases with immersion time; one order of magnitude for the reference substrate (not modified superficially) and up to three orders of magnitude for implanted substrates, note that in the samples implanted with $\mathrm{Ti}$ ions for $10 \mathrm{~min}$ a sudden drop in capacitance is recorded in the 28th day of trial, which reaches a decrease of 9 orders of magnitude.

Increased capacitance is possibly due to the penetration of electrolytes through the corrosion products that are formed in the surface of the specimens (Escobar et al., 2013). Other authors describe the increase in capacitance as the result of an increased porosity of the layers of the corrosion products presented (Cottis \& Turgoose, 1999), whereas the decreased capacitance of the Ti substrate implanted with ions during $10 \mathrm{~min}$ on the 28 th day of immersion may be related to changes 


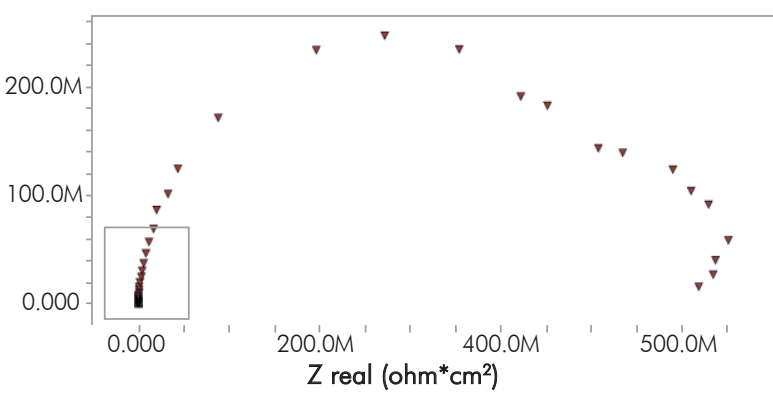

(a)

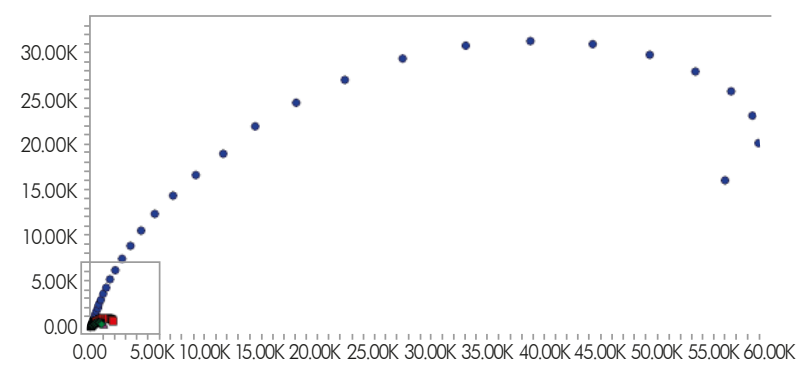

$\mathrm{Z}$ real $\left(\mathrm{ohm}^{*} \mathrm{~cm}^{2}\right)$

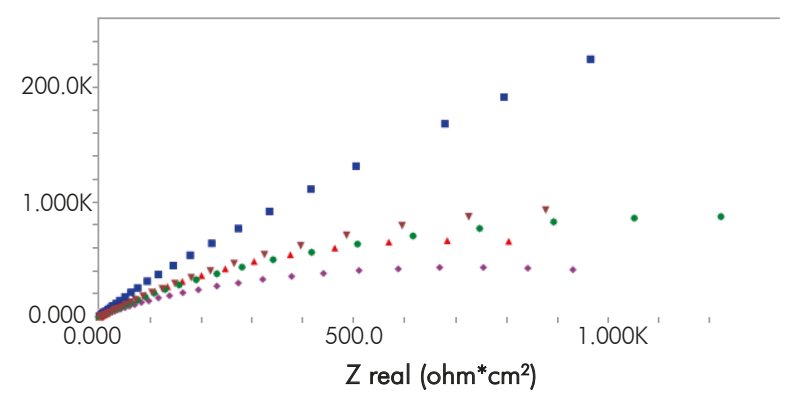

(b)

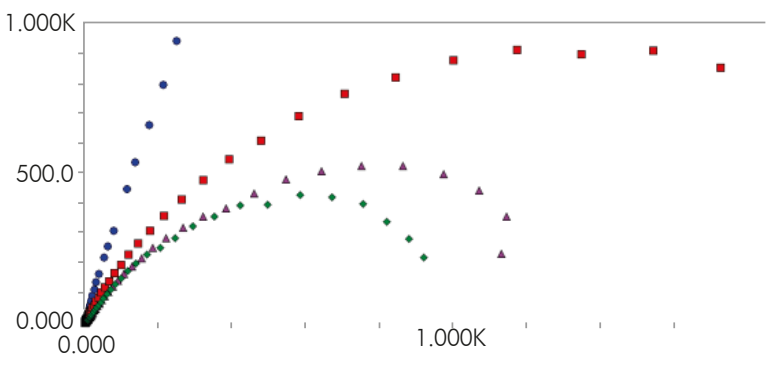

$Z$ real $\left(\mathrm{ohm}^{*} \mathrm{~cm}^{2}\right)$

(c)

\section{0 days $\quad 7$ days $\triangle 15$ days $\leadsto 21$ days $\quad \forall 28$ days}

Figure 4. Nyquist plots for samples implanted with Ti 10kV (a) for 10 min, (b) for $5 \mathrm{~min}$, (c) Zoom of insert (a), (d) Zoom of insert (c).

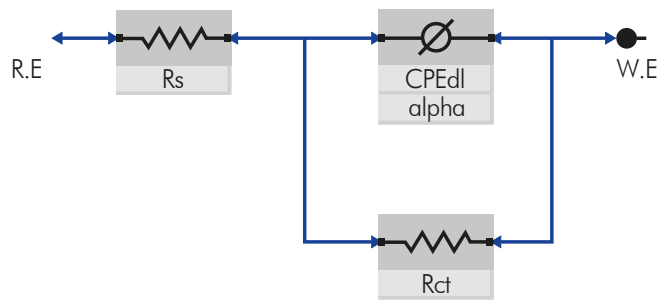

(a)

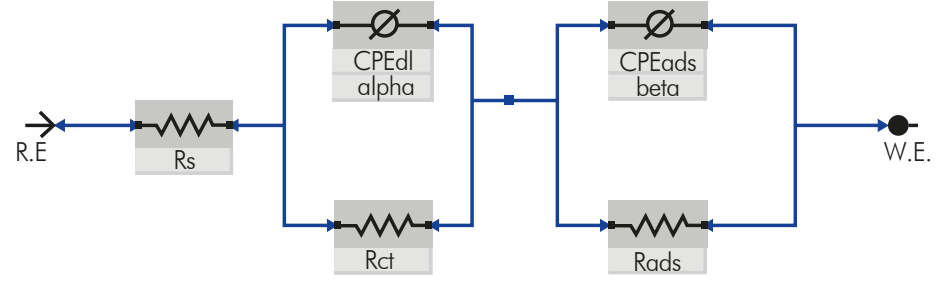

(b)

Figure 5. (a) Equivalent circuit used to simulate the implanted samples, and non implanted samples immersed 0 days and 7 days. (b) Circuit used to simulate the behavior of the non implanted substrate from 15 to 28 days of immersion..

Table 1. EIS corresponding values of the parameters for the reference substrate.

\begin{tabular}{|c|c|c|c|c|c|c|c|c|c|c|}
\hline \multirow{2}{*}{ Parameter } & \multicolumn{10}{|c|}{ Days } \\
\hline & 0 & \pm error & 7 & \pm error & 15 & \pm error & 21 & \pm error & 28 & \pm error \\
\hline 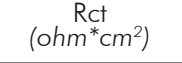 & 244.30 & 2.48 & 51.34 & 0.77 & 62.19 & 1.49 & 37.67 & 0.51 & 64.61 & 8.61 \\
\hline $\begin{array}{c}\text { CPE } \\
\left(\mathrm{S}^{*} \mathrm{~s}^{a}\right) /\left(\mathrm{cm}^{2}\right)\end{array}$ & $5.88 \mathrm{E}-\mathrm{A}$ & $4 \mathrm{E}-06$ & $7.13 \mathrm{E}-04$ & $1 \mathrm{E}-05$ & 1.02E-03 & $2 \mathrm{E}-05$ & 8.09E-04 & $2 \mathrm{E}-05$ & $1.05 \mathrm{E}-03$ & $4 \mathrm{E}-05$ \\
\hline$\alpha$ & $9.04 \mathrm{E}-1$ & 7E-06 & 8.83E-01 & 3E-03 & 8.25E-01 & $4 \mathrm{E}-03$ & 8.69E-01 & $4 \mathrm{E}-03$ & $8.11 \mathrm{E}-01$ & $1 \mathrm{E}-02$ \\
\hline Xi squared & $3.10 \mathrm{E}-2$ & & $1.84 \mathrm{E}-03$ & & $3.42 \mathrm{E}-03$ & & 1.82E-02 & & $2.15 \mathrm{E}-03$ & \\
\hline $\begin{array}{c}\text { KramersKronig } \\
\mathrm{Xi}^{2}\end{array}$ & $1.51 \mathrm{E}-3$ & & $9.10 \mathrm{E}-04$ & & 2.07E-03 & & $1.10 \mathrm{E}-02$ & & $1.47 \mathrm{E}-03$ & \\
\hline
\end{tabular}


Table 2. EIS corresponding values of the parameters for samples implanted with $\mathrm{Ti}+\mathrm{N}$ for $5 \mathrm{~min}$

\begin{tabular}{|c|c|c|c|c|c|c|c|c|c|c|}
\hline \multirow{2}{*}{ Parameter } & \multicolumn{10}{|c|}{ Days } \\
\hline & 0 & \pm error & 7 & \pm error & 15 & \pm error & 21 & \pm error & 28 & \pm error \\
\hline $\begin{array}{c}\text { Rct } \\
\left(\mathrm{ohm}^{*} \mathrm{~cm}^{2}\right)\end{array}$ & 620.90 & 5.94 & 236.30 & 2.31 & 188.30 & 1.68 & 221.60 & 2.24 & 212.90 & 2.85 \\
\hline $\begin{array}{c}\mathrm{CPE} \\
\left(\mathrm{S}^{*} \mathrm{~s}^{\mathrm{a}}\right) /\left(\mathrm{cm}^{2}\right)\end{array}$ & 3.99E-04 & $5 \mathrm{E}-06$ & $2.28 \mathrm{E}-03$ & $3 \mathrm{E}-05$ & 4.14E-03 & $4 \mathrm{E}-05$ & 7.23E-03 & $6 \mathrm{E}-05$ & 1.19E-02 & $1 \mathrm{E}-04$ \\
\hline$\alpha$ & $8.64 \mathrm{E}-01$ & $5 \mathrm{E}-03$ & 7.99E-01 & $2 \mathrm{E}-03$ & $7.23 E-01$ & $2 \mathrm{E}-03$ & 8.57E-01 & $2 \mathrm{E}-03$ & $8.16 \mathrm{E}-01$ & $2 \mathrm{E}-03$ \\
\hline$X_{i}$ squared & $2.67 \mathrm{E}-02$ & & $6.03 E-04$ & & $6.98 \mathrm{E}-03$ & & $3.44 \mathrm{E}-03$ & & $1.71 \mathrm{E}-03$ & \\
\hline $\begin{array}{c}\text { KramersKronig } \\
\mathrm{Xi}^{2}\end{array}$ & $6.21 \mathrm{E}-04$ & & $1.51 \mathrm{E}-04$ & & 7.12E-03 & & $1.26 \mathrm{E}-03$ & & 1.35E-03 & \\
\hline
\end{tabular}

Table 3. EIS corresponding values of the parameters for samples implanted with $\mathrm{Ti}+\mathrm{N}$ for $10 \mathrm{~min}$.

\begin{tabular}{|c|c|c|c|c|c|c|c|c|c|c|}
\hline \multirow{2}{*}{ Parameter } & \multicolumn{10}{|c|}{ Days } \\
\hline & 0 & \pm error & 7 & \pm error & 15 & \pm error & 21 & \pm error & 28 & \pm error \\
\hline $\begin{array}{c}\text { Rct } \\
\left(\text { ohm } \mathrm{cm}^{2}\right)\end{array}$ & 2415.00 & 21.62 & 226.90 & 2036.00 & 144.50 & 1306.00 & 190.00 & 2432.00 & 316.60 & 4270.00 \\
\hline $\begin{array}{c}\mathrm{CPE} \\
\left(\mathrm{S}^{*} \mathrm{~s}^{a}\right) /\left(\mathrm{cm}^{2}\right)\end{array}$ & $9.00 E-05$ & $9 \mathrm{E}-07$ & $1.35 \mathrm{E}-03$ & $2 \mathrm{E}-05$ & $1.95 \mathrm{E}-03$ & $2 \mathrm{E}-05$ & 4.83E-03 & $5 \mathrm{E}-05$ & 7.31E-03 & $6 \mathrm{E}-05$ \\
\hline$\alpha$ & 8.76E-01 & $1 \mathrm{E}-03$ & 8.22E-01 & $2 \mathrm{E}-03$ & 8.72E-01 & $2 \mathrm{E}-03$ & $1.00 \mathrm{E}+00$ & $2 \mathrm{E}-03$ & 7.24E-01 & $2 \mathrm{E}-03$ \\
\hline Xi squared & 8.03E-02 & & $5.68 \mathrm{E}-03$ & & $8.92 \mathrm{E}-03$ & & $5.73 \mathrm{E}-02$ & & $1.95 \mathrm{E}-03$ & \\
\hline $\begin{array}{c}\text { KramersKronig } \\
\mathrm{Xi}^{2}\end{array}$ & $9.71 \mathrm{E}-04$ & & $2.73 \mathrm{E}-04$ & & 3.30E-03 & & $5.64 \mathrm{E}-02$ & & $9.42 \mathrm{E}-05$ & \\
\hline
\end{tabular}

Table 4. EIS corresponding values of the parameters for samples implanted with Ti for $5 \mathrm{~min}$.

\begin{tabular}{|c|c|c|c|c|c|c|c|c|c|c|}
\hline \multirow{2}{*}{ Parameter } & \multicolumn{10}{|c|}{ Days } \\
\hline & 0 & \pm error & 7 & \pm error & 15 & \pm error & 21 & \pm error & 28 & \pm error \\
\hline $\begin{array}{c}R c \dagger \\
\left(o h m^{*} \mathrm{~cm}^{2}\right)\end{array}$ & 325200.00 & 3289.00 & 2146.00 & 52.16 & 1611.00 & 36.92 & 3420.00 & 128.40 & 4567.00 & 277.80 \\
\hline $\begin{array}{c}\mathrm{CPE} \\
\left(\mathrm{S}^{*} \mathrm{~S}^{a}\right) /\left(\mathrm{cm}^{2}\right)\end{array}$ & 5.98E-06 & $4 \mathrm{E}-08$ & 1.86E-03 & $1 \mathrm{E}-05$ & 3.57E-03 & $2 \mathrm{E}-05$ & $3.72 \mathrm{E}-03$ & $2 \mathrm{E}-05$ & 4.19E-03 & 3E-05 \\
\hline$\alpha$ & $8.11 \mathrm{E}-01$ & $9 \mathrm{E}-04$ & $7.21 \mathrm{E}-01$ & $2 \mathrm{E}-03$ & $6.70 \mathrm{E}-01$ & $1 \mathrm{E}-03$ & 7.09E-01 & $1 \mathrm{E}-03$ & 7.26E-01 & $2 \mathrm{E}-03$ \\
\hline Xi squared & 4.24E-02 & & $2.38 \mathrm{E}-02$ & & $1.18 \mathrm{E}-02$ & & $1.14 \mathrm{E}-02$ & & $1.92 \mathrm{E}-03$ & \\
\hline $\begin{array}{c}\text { KramersKronig } \\
\mathrm{Xi}^{2}\end{array}$ & 7.52E-04 & & $2.96 \mathrm{E}-04$ & & 6.66E-05 & & $4.45 \mathrm{E}-05$ & & $3.26 \mathrm{E}-05$ & \\
\hline
\end{tabular}

Table 5. EIS corresponding values of the parameters for samples implanted with Ti for $10 \mathrm{~min}$.

\begin{tabular}{|c|c|c|c|c|c|c|c|c|c|c|}
\hline \multirow{2}{*}{ Parameter } & \multicolumn{10}{|c|}{ Days } \\
\hline & 0 & \pm error & 7 & \pm error & 15 & \pm error & 21 & \pm error & 28 & \pm error \\
\hline $\begin{array}{c}R_{c \dagger}+ \\
\left(o h m^{*} \mathrm{~cm}^{2}\right)\end{array}$ & 67940.00 & 734.10 & 1898.00 & 20.59 & 1828.00 & 39.46 & 1578.00 & 38.19 & $5.78 \mathrm{E}+08$ & $4.7 E+06$ \\
\hline $\begin{array}{c}\mathrm{CPE} \\
\left(\mathrm{S}^{*} \mathrm{~s}^{a}\right) /\left(\mathrm{cm}^{2}\right)\end{array}$ & $2.98 \mathrm{E}-05$ & $2 \mathrm{E}-07$ & $1.40 \mathrm{E}-03$ & $1 \mathrm{E}-05$ & $2.55 \mathrm{E}-03$ & $2 \mathrm{E}-05$ & $3.44 \mathrm{E}-03$ & $3 E-05$ & $1.10 \mathrm{E}-11$ & $2 E-13$ \\
\hline$\alpha$ & $8.85 \mathrm{E}-01$ & $9 \mathrm{E}-04$ & 8.90E-01 & $1 \mathrm{E}-03$ & $6.68 \mathrm{E}-01$ & $2 \mathrm{E}-03$ & $6.53 \mathrm{E}-01$ & $2 \mathrm{E}-03$ & $9.68 \mathrm{E}-01$ & $1 \mathrm{E}-03$ \\
\hline Xi squared & $3.76 \mathrm{E}-02$ & & $5.24 \mathrm{E}-02$ & & $5.43 \mathrm{E}-03$ & & 8.37E-02 & & 5.90E-03 & \\
\hline $\begin{array}{c}\text { KramersKronig } \\
\mathrm{Xi}^{2}\end{array}$ & $2.86 \mathrm{E}-04$ & & $4.32 \mathrm{E}-04$ & & $2.17 \mathrm{E}-04$ & & $5.60 \mathrm{E}-05$ & & $4.30 \mathrm{E}-04$ & \\
\hline
\end{tabular}




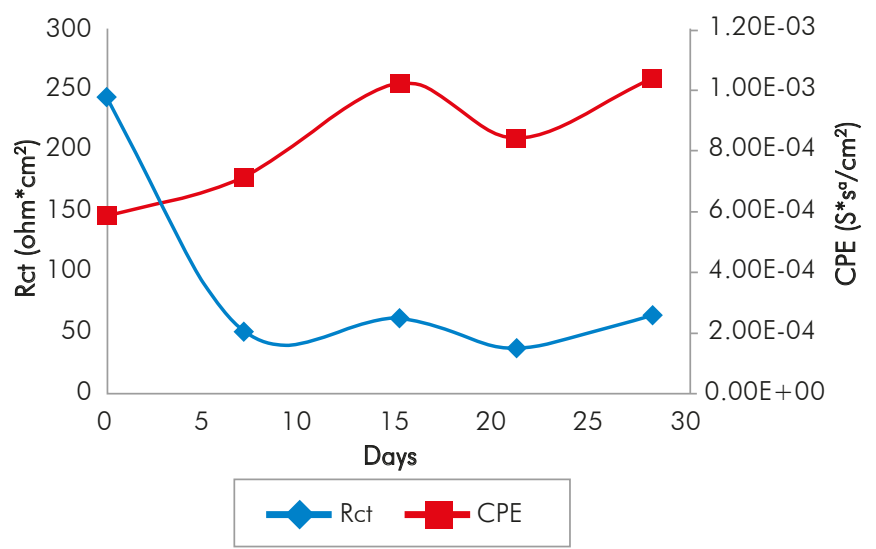

Figure 7. Resistance to charge transfer and capacitance versus immersion time for the reference substrate.

in morphology of corrosion products layers formed on the surface possibly becoming a homogeneous passive layer (Cottis \& Turgoose, 1999). The resistance to charge transfer for the conditions studied, except for the implantation with Ti for $10 \mathrm{~min}$, has the characteristic of

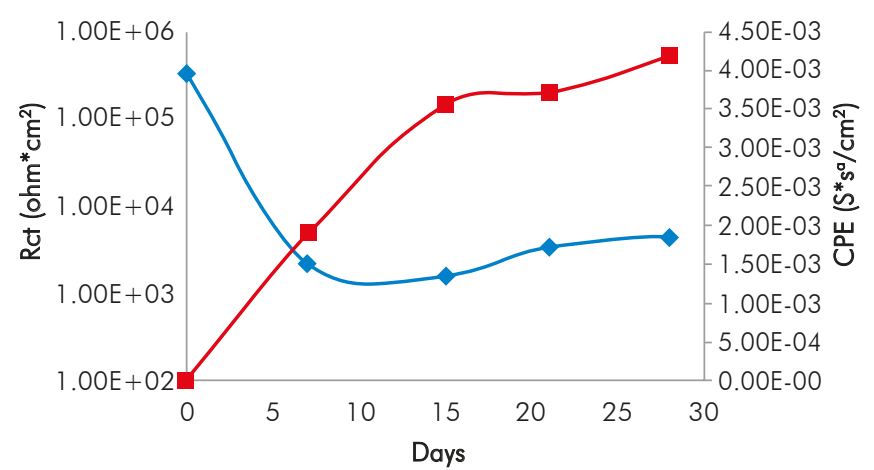

(a)

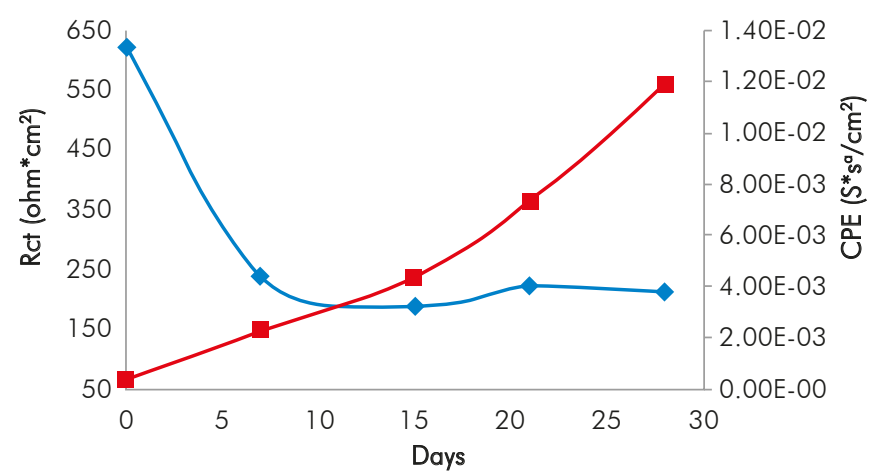

(c) starting in a maximum and then decrease and stabilize 1 order of magnitude below the initial value for the substrate, 2 orders of magnitude below the initial value to the Ti for $5 \min$ and $\mathrm{Ti}+\mathrm{N}$ for $10 \mathrm{~min}$, and decrease 3 times under baseline conditions for the implantation of $\mathrm{Ti}+\mathrm{N}$ for $5 \mathrm{~min}$.

The samples implanted with Ti ions for $10 \mathrm{~min}$ have a different behavior, since the resistance to charge transference increases about 5 orders of magnitude between day 21 and day 28 and remains up to 4 orders of magnitude above the initial value. Increased resistance to charge transference indicates that the corrosion process is disadvantageous (Flores-Merino \& PaucarCuba, 2003; Cabrera-Sierra, Marín-Cruz \& González, 2007; Galván et al., 2016; Chang, 2016) possibly due to the presence of a passive film that becomes more stable in time (Galván et al., 2016; Vasilescu et al., 2015).

The open circuit corrosion potential is one of the

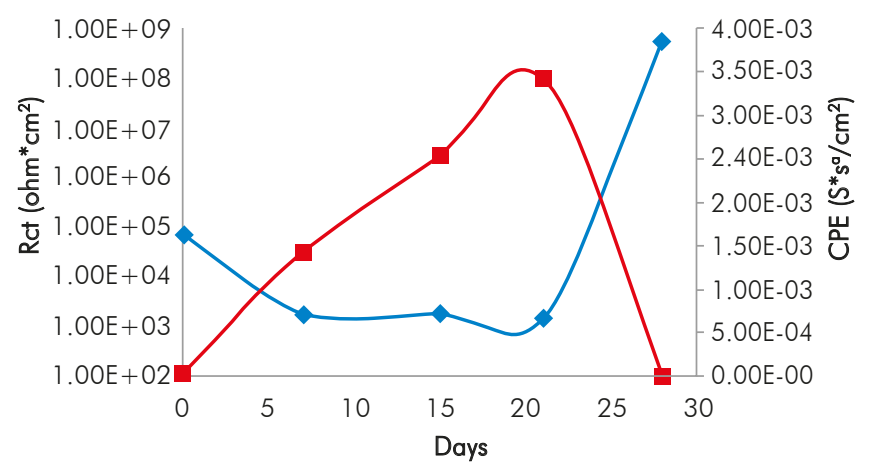

(b)

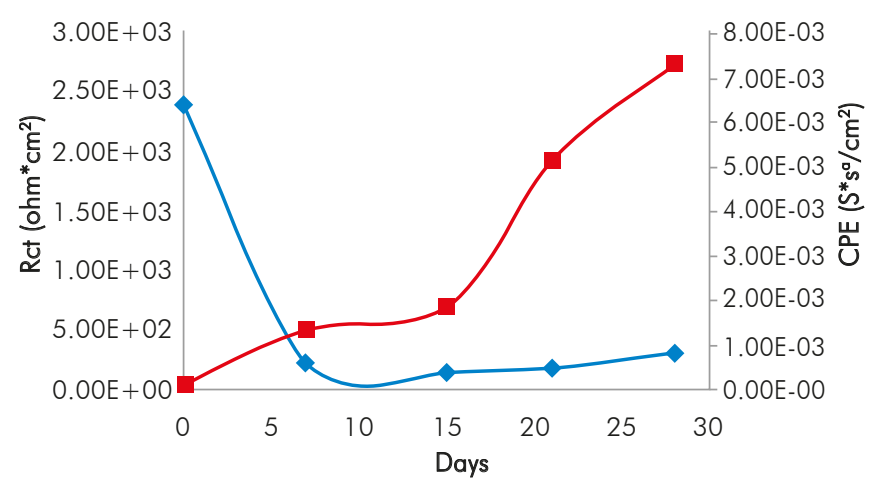

(d)

\section{$\smile$ Rct - CPE}

Figure 8. Resistance to charge transfer and capacitance versus immersion time for substrates implanted with (a) Ti+N for $5 \mathrm{~min}$, (b) $\mathrm{Ti}+\mathrm{N}$ for $10 \mathrm{~min}$, (c) Ti for $5 \mathrm{~min}$, and (d) Ti for $10 \mathrm{~min}$. 
tools to find out the tendency of an electrochemical system to corrode or not, where higher thermodynamic potential tendency for low corrosion may take place and vice versa. Figure 9 shows that at 0 days samples implanted in all conditions have corrosion potential between 100 and $140 m V$ higher than the non-implanted substrate, indicating that implanted samples have a lower thermodynamic tendency to corrosion as compared to substrates without implantation. However after 7 days immersion, there are two subgroups with different trends, the group formed by the samples implanted with Ti ions for 5 and $10 \mathrm{~min}$, whose potential is above the corrosion potential of the non-implanted substrate, meaning it is less prone to corrode. The second subgroup comprises the specimens implanted with $\mathrm{Ti}+\mathrm{N}$ ions for 5 and $10 \mathrm{~min}$, whose potential is below the corrosion potential of the substrate of reference, indicating that the specimens implanted with $\mathrm{Ti}+\mathrm{N}$ ions have a higher thermodynamic tendency to corrosion as compared to the non-implanted substrate.

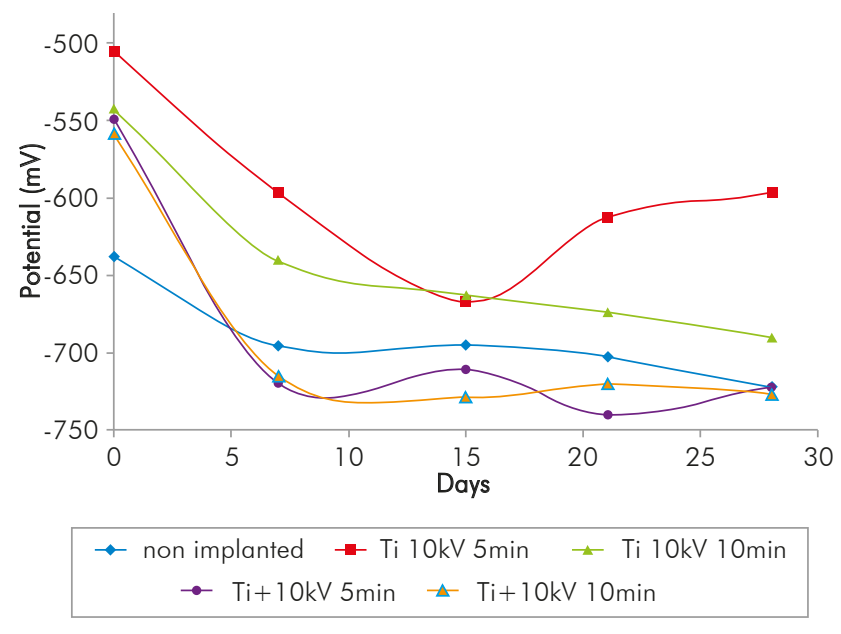

\section{CONCLUSIONS}

- The EIS spectra of the substrates implanted and non-implanted presented only one time constant $\tau$, which allows us to conclude that the implanted ions do not form a film as in a coating, but instead they fully integrate with the substrate, the behavior of the implanted samples can be simulated by using one equivalent circuit, which has a constant phase element instead of a capacitor, and the behavior of the non implanted substrates from day 15 to 28 can be simulated with one equivalent circuit, which has two constant phase elements instead of two capacitors.
- The electrochemical double layer formed on the interface between samples, implanted and non-implanted, and the surrounding electrolyte, showed a capacitive behavior, because the values of $\alpha$ obtained from the EIS test were between 0.5 and 1 .

- According to the charge transference resistance, all surfaces implanted have best corrosion resistance when compared to the non-implanted surface. The decrease in the capacitance of samples implanted with Ti ions for $10 \mathrm{~min}$ and $10 \mathrm{kV}$ on the $28 \mathrm{th}$ day, may be related to the changes in morphology due to corrosion products and the layers homogeneous passive characteristics of $\mathrm{TiO}_{2}$ formed on the surface.

- According to the open circuit potential measurements the Ti ions implanted samples have less tendency to corrode. The Rct of the specimens implanted with $\mathrm{Ti}$ ions showed a higher corrosion resistance than surfaces implanted with $\mathrm{Ti}+\mathrm{N}$ and non-implanted. The best corrosion performance was obtained by specimens implanted with $\mathrm{Ti}$ ions for $10 \mathrm{~min}$ and $10 \mathrm{kV}$. Further studies will be conducted to analyze the morphology and composition of the surface and corrosion product layers before and after immersion, to confirm the layer passive characteristics.

\section{ACKNOWLEDGEMENTS}

The authors thank the FITEK group of the Universidad Industrial de Santander, Group of Physics Mesoscopic of the Universidad Nacional de Colombia, CECOB of the Universidad Nacional Experimental Politécnica Antonio José de Sucre and DIM-ETSII of the Univeridad Politécnica de Madrid for the generous collaboration.

\section{REFERENCES}

Cabrera-Sierra, R., Marín-Cruz, J. \& González, I. (2007). La utilización de la espectroscopia de impedancia electroquímica (EIS) para identificar diferentes estados superficiales en el proceso de corrosión del acero al carbono en medios amargos. Bol. Soc. Quím. Méx., 1(1), 32-41.

Chang, M., Su, J., Hu, G., Zhai, B., Meng, D., Sun, L., Chen, Y., Li, Y. \& Cui, Y. (2016). Enhancement of corrosion resistance of a biomedical grade NiTi shape memory alloy by cyclic potentiodynamic polarization in PBS solution. Int. J. Electrochem. Sci., 11: 1092-1098. 
Cottis, R. \& Turgoose, S. (1999). Electrochemical impedance and noise. Houston: NACE International.

Dougar-Jabon, V. D., Dulce-Moreno, J. \& Tsygankov, P. A. (2002). High voltage pulse discharge for ion treatment of metals. Rev. Sci. Instrum., 73(2), 828-830. doi:10.1063/1.1429785.

Dugar-Zhabon, V. D., Dulcé-Moreno, H. J., Garnica-Villamizar, H. A. \& Valbuena-Niño, E. D. (2012). A new method for surface modifications of carbon steels and alloys. Materials Research, 15(6), 969-973. doi: 10.1590/S151614392012005000133.

Dulce-Moreno, H. J., Tsygankov, P. A., Dugar-Zhabon, V., V. Niño, E. D. \& Parada, F. F. (2011). Estudio de los haces electrónicos en la descarga eléctrica de alto voltaje a bajas presiones. Puente Revista Científica, 5(2), 21-26.

Escobar, C., Caicedo, J. C., Aperador, W., Delgado, A. \& Prieto, P. (2013). Improve on corrosion resistant surface for AISI 4140 steel coated with VN and HfN single layer films. Int. J. Electrochem. Sci., 8: 7591-7607.

Flores-Merino, S. \& Paucar-Cuba, K. M. (2003). Evaluación de sistemas de recubrimientos mediante espectroscopia de impedancia electroquímica (ESI). Jornadas SAM/ CONAMET-Simposio de Materiales. Bariloche, Argentina.

Galván, J. C., Larrea, M. T., Braceras, I., Multigner, M. \& González-Carrasco, J. L. (2016). In vitro corrosion behaviour of surgical 316LVM stainless steel modified by $\mathrm{Si}+$ ion implantation - An electrochemical impedance spectroscopy study. J. Alloys Compd., 676: 414-427. doi:10.1016/j.jallcom.2016.03.162.

Gil, L., Jiménez, L. \& Staia, M. (2006). Evaluación del efecto de la aplicación de un recubrimiento de Ni-P sobre la resistencia a la corrosión de la aleación de aluminio 7075T6. Universidad, Ciencia y Tecnología, 10(39), 115-118.

Hernández, L., Gil, L., Niño, E., Noriega, R. \& Angulo, N. (2014). Evaluación experimental de la implantación tridimensional de iones $\mathrm{Ti}$ y $\mathrm{TiN}$ en la resistencia a la corrosión del acero AISI SAE 4140. XII Jornadas de Investigación UNEXPO. Puerto Ordaz, Venezuela.

Khvesyuk, V. I. \& Tsygankov, P. A. (1997). The use of a highvoltage discharge at low pressure for 3D ion implantation.
Surf. Coat. Technol., 96(1), 68-74. doi:10.1016/S02578972(97)00117-5.

Parada-Becerra, F., Cabanzo, R., Dugar-Zhabon, V., Tsygankov, P., Mejia-Ospino, E. \& V. Niño, E. D. (2012). Plasma temperature measurement in a hybrid discharge by using optical diagnostics. J. Phys.: Conf. Ser., 370. doi:10.1088/1742-6596/370/1/012054.

Peña, D., Fontalvo, P., Estupiñán, H., Niño, D. \& Vesga, W. (2009). Evaluación experimental de la Resistencia a la corrosión de un acero AISI-SAE 4140 implantado con iones de nitrógeno. Dyna, 76(159), 43-52.

Tsygankov, P., Plata, A., V. Niño, E. D., Ochoa, C., Parada, F., Chacón, C. \& Dugar-Zhabon, V. (2011). Estudio de características voltio-ampéricas y peculiaridades de funcionamiento de un vaporizador de arco en vacío. Rev. Col. Fís., 43(2), 458-462.

V. Niño, E. D. \& Dougar-Jabon, V. D. (2006). Comportamiento del acero SAE-4140 implantado con iones de nitrógeno en ambientes hidrogenados. Rev. Col. Fís., 38(1), 61-64.

V. Niño, E. D., Dugar-Zhabon, V., Dulce-Moreno, J., PeñaRodríguez, G., Garnica, H. A. \& Tsygankov, P. (2012). Aplicación de descargas simultáneas de alto voltaje y arco eléctrico para el tratamiento superficial avanzado de metales. Iteckne, 9(1), 14-20, doi: 10.15332/iteckne.v9i1.56.

V. Niño, E. D., Peña, D. Y., Reyes, M. S. \& Dugar-Zhabon, V. D. (2013). Estudio experimental de la resistencia a la corrosión de un acero al carbono AISI-SAE 1020 implantado con iones de titanio. Rev. LatinAm. Metal. Mat., 33(1), 138-146.

V. Niño, E. D., Salinas, D. V., Peña, D. Y. \& Chinchilla, L. F. (2011). Modificación superficial de un acero AISI SAE 1045 mediante la implantación de iones de nitrógeno y titanio. Iteckne, 8(1), 31-36. doi: 10.15332/iteckne.v8i1.259.

Valbuena-Niño, E. D., Dulcé, H. J. \& Dugar-Zhabon, V. (2010). Caracterización del acero AISI 4140 implantado por iones de nitrógeno. Rev. Col. Fís., 42(3), 387-392.

Vasilescu, C., Drob, S., Calderon-Moreno, J., Osiceanu, P., Popa, M., Vasilescu, E., Marcu, M. \& Drob, P. (2015). Longterm corrosion resistance of new Ti-Ta-Zr alloy in simulated physiological fluids by electrochemical and surface analysis methods. Corrosion Science, 93: 310-323. doi:10.1016/j. corsci.2015.01.038. 


\section{AUTHORS}

Ely-Dannier Valbuena-Niño

Affiliation: Universidad Politécnica de Madrid - Universidad

Industrial de Santander

Physics, Universidad Industrial de Santander

M.Sc. in Physics, Universidad Industrial de Santander

Ph.D. student in Mechanical Engineering, Universidad Politéc-

nica de Madrid

e-mail: deydannv@gmail.com

\section{Linda Gil}

Affiliation: Universidad Nacional Experimental Politécnica Materials Engineering, Mention Metallurgy, Universidad Simón Bolivar

M.Sc. in Metallurgy and Materials Science, Instituto Venezolano de Investigaciones Cientificas

Ph.D. in Sciences, Mention Metallurgy and Materials Science, Universidad Central de Venezuela

e-mail: lindaegil@gmail.com

\section{Luis Hernández-Molina}

Affiliation: Universidad Nacional Experimental Politécnica Chemistry technician, Instituto Universitario de Tecnología José Antonio Anzoátegui Metallurgical Engineer, Universidad Nacional Experimental Politécnica Antonio José de Sucre e-mail: lahernandez@unexpo.edu.ve

\section{José-José Barba-Ortega}

Affiliation: Universidad Nacional de Colombia Physics, Universidad Industrial de Santander M.Sc. in Physics, Universidad Industrial de Santander Ph.D. in Physics, Universidade Federal de Pernambuco e-mail:jjbarbao@unal.edu.co

\section{Valeriy Dugar-Zhabon}

Affiliation: Universidad Industrial de Santander

Physics, Moscow State University

M.Sc. in Physics, Moscow State University

Ph.D. in Physics and Mathematical, Peoples' Friendship University of Russia

e-mail: vdougar@uis.edu.co 
